UDK 327(497:73)

Samostalni istraživač, Beograd

\title{
TEORIJSKI I DOKTRINARNI OKVIRI NAMETANJA AMERIČKOG UTICAJA NA BALKANU 1990-IH GODINA
}

\section{Rezime}

Američka spoljna politika u postbipolarnoj eri zasnivala se na unilateralizmu Zapada, kako teorijski tako i institucionalno, nalazeći oslonac u liberalizmu, ali i neorealizmu jer je oba pogleda na svet nadahnuo utilitarizam, korist koju predvodi interes Vašingtona. Niz teoretičara i činovnika obe administracije predsednika Klintona su 1990-ih godina uticale na svet neovilsonovskim nametanjem svoje vrste demokratije i angažovanjem uticaja, nepovratno umanjujući konsenzus u Ujedinjenim nacijama. Amerika je samo sebi dozvolila važne odluke koje su ipak pravdane međunarodnim pravom uvodeći političke presedane objašnjavane tako da se predstave moralno neophodnim. Naknadno traženje legitimiteta od Saveta bezbednosti UN za humanitarnu intervenciju, dalo je osnov opstanku UN, ali su postigle trajno nepoverenje manjih naroda, naročito Srba koji su na Balkanu osetili neprincipijelnosti spoljne politike Vašingtona.

Ključne reči: Amerika, teorija, institucije, liberalizam, realizam, Balkan.

\section{NOVI SVETSKI POREDAK}

Četrdeset prvi američki predsednik Džordž Herbert Voker Buš (George Herbert Walker Bush) prvi put je upotrebio sintagmu „Novi svetski poredak" (New World Order) obraćajući se 11. septembra 1990. godine Kongresu Sjedinjenih Američkih Država (SAD) o krizi u Persijskom zalivu i deficitu budžeta: „cilj - novi svetski poredak - može nastati: novo doba - oslobođeno pretnje terorom, snažnije u potrazi za pravdom i sigurnije u potrazi za mirom... U krajnjem slučaju, naša sposobnost da ispunimo svoje odgovornosti u inostranstvu zavisi od političke volje i konsenzusa kod kuće" (Bush, 1990). Odgovornost vođstva i samostalnost odlučivanja je još bila u stavu saradnje i usaglašavanja sa još postojećim Savezom Sovjetskih Socijalističkih Republika (SSSR). Prvi izazov novog poretka bio je Irak, na čiju su stranu i udaljenu obalu američki vojnici krenuli kada su SAD imale odobrenje Ujedinjenih nacija (United Nations - UN).

Novi svet bi bio bez hladnoratovskog trvenja. Ovim je označen početak novog razdoblja međunarodnih odnosa uzrokovan promenama koje su izmenile do tada bipolarnu ravnotežu u svetu. Univerzalne teženje čovečanstva su time usvojene kao legitimacija budućih intervencija SAD koje će evoluirati u narednih devet godina preko duplog ključa odlučivanja UN

${ }^{1}$ posaovss@yahoo.com 
i NATO (North Atlantic Treaty Organisation) povodom ratnih događanja u

Bosni do trenutka kada SAD više i neće pitati UN za odobrenje akcija na prostoru Savezne Republike Jugoslavije (SRJ).

Generalni sekretar UN Butros Butros Gali (Boutros Boutros-Ghali) je u „Agendi za mir“ 1992. godine naveo novu ulogu UN u razvoju novog koncepta međunarodne bezbednosti. Istaknut je značaj prevencije kriza i sukoba i ponuđena velika ovlašćenja Savetu bezbednosti UN. Prevencija konflikata sastojala bi se od četiri nivoa - preventivne diplomatije, uspostave, očuvanja i građenja mira. UN u Vašingtonu više nisu bile smatrane važnim, kao da su ispunile svoju svrhu, što se vidi po tome da SAD više nisu ni plaćale svoj deo članarine za funkcionisanje ove univerzalne međunarodne organizacije kao da se očekivalo da nestane. Tada je pre trebalo očekivati da nestane NATO jer mu se rival, Varšavski pakt (Договор о дружбе, сотрудничестве и взаимнной помощи), pa i SSSR sam raspao.

\section{KRAJ BIPOLARIZMA}

Novi svetski poredak koji je SAD kao jedina preostala supersila počela da reguliše dao je i svoje teorijske osnove u literaturi. Frensis Fukujama (Francis Fukuyama) u članku „Kraj istorije?““ objavljenom još 1989. godine u časopisu Nešnl intrest (The National Interest) smatra završetak Hladnog rata pobedom liberalne demokratije, zapadnih pogleda na svet i kapitalističkog uređenja tržišta koje je krajnja tačka sociokulturne evolucije čovečanstva (Fukuyama, 1989). Na drugoj strani u časopisu Forin Afers (Foreign Affairs) pojavili su se članci isto tako važni za opis novog doba koje nastupa. Čarls Krauthajmer (Charles Krauthammer) objavljuje 1991. godine članak sa naslovom „Unipolarni momenat“ u kome navodi da se očekivana multipolarnost neće još ostvariti kao ni internacionalizam (Krauthammer, 1991).

Semjuel Filips Hantington (Samuel Phillips Huntington) u članku „Sudar civilizacija“ koji je nastao u okviru projekta „Izmenjeno bezbednosno okruženje i američki nacionalni interesi“" smatra ovo razdoblje krajem ideološke, blokovske podele sveta transformišući ga u okvirima civilizacija formiranih po bliskosti kultura. Zapad je sada na izuzetnom vrhuncu moći u odnosu na ostale civilizacije, kaže Hantington u ovom članku iz 1993. godine, i to da je moćni protivnik zapada nestao sa mape sveta, da je vojni sukob unutar zapadnih zemalja nezamisliv, a zapadna vojna moć je bez premca (Huntington 1993). Globalna politička i bezbednosna pitanja se efikasno rešavaju pod direktoratom SAD, Britanije i Francuske a svetski ekonomski problemi pod upravom SAD, Nemačke i Japana, tvrdi Hantinton. Zaista u to doba kada je SSSR prestao da postoji, nove sile koje su se pridružile spisku sila su postale Namačka i Japan (Bergner, 1994). Hantington poentira: „Odluke koje se donose u Savetu bezbednosti UN ili Međunarodnom monetarnom fondu i odražavaju interese Zapada prezentiraju se ostalima kao željeni cilj svetske zajednice u celini“ (Huntington, 1993: 39). Sam izraz „svetska zajednica“ (the world community) je postao opšteprihvaćeni eufemizam, zamenjujući izraz slobodni svet (the free world) koji pruža legitimitet aktima koji odražavaju interese SAD i ostalih zapadnih sila (Ibid.). 
Hantington navodi da lideri Zapada skoro uvek tvrde da deluju u ime ,svetske zajednice" i da se jedan manji izuzetak dogodio kada je britanski ministar spoljnih poslova Džon Mejdžor u intervjuu za Gud morning Amerika (Good Morning America) 21. decembra 1990. godine govorio o akcijama „Zapada“ usmerenim protiv Sadama Huseina, brzo se ispravivši da je pod tim mislio na „svetsku zajednicu“ (Ibid.). Ubrzo je izraz „,međunarodna zajednica“" (international community) postao sinonim za Zapad.

Osim naučne elite, novim dobom bavili su se i politički stratezi. Pol Volfovic (Paul Dundes Wolfowitz), podsekretar Dika Čejnija (Richard Bruce Cheney) za politiku odbrane SAD je februara 1992. godine sa svojim zamenikom Irving Luis Libijem (Irving Lewis Libby) sastavio dokument Pentagona od četrdeset šest strana poznat kao „Smernice planiranja odbrane za fiskalne godine 1994-99“ ili jednostavno Volfoviceva doktrina u kojoj se navodi pravo SAD da interveniše kada i gde veruje da je potrebno tako da se odbacuje kolektivni internacionalizam UN-a i uvodi američki primat kao supersile sa pravom na unilateralizam i intervencionizam radi obezbeđenja izvora nafte i osujećivanja rivala ili kratko rečeno očuvanje imperijalnih interesa. Tekst između ostalog tvrdi da: „S jedne strane SAD ne može da postane svetski ,policajac', preuzimanjem odgovornosti za ispravljanje svih pogrešnosti, pa ipak mi ćemo zadržati nadmoćnu odgovornost za selektivno rešavanje one nepravde koje prete bilo samo našim interesima, ili naših saveznika ili prijatelja, ili koje bi mogle ozbiljno da uzdrmaju međunarodne odnose" (Gellman, 1992: 1) Ovaj dokument će kao aksiom odrediti pravac globalne supremacije SAD za sledeći vek i postati opravdanje za američko vojno mešanje širom sveta iako su republikanci i uopšte konzervativci izgubili odlučujući glas o ovim pitanjima smenom na čelu SAD.

\section{LIBERALIZAM I REALIZAM U AMERICI}

Sociolog Sejmur Martin Lipset (Seymour Martin Lipset), koji je veliki deo karijere proveo tumačeći koliko se Sjedinjene Države razlikuju od drugih razvijenih demokratija, ima običaj da kaže da američki konzervativizam nije manje poseban i drugačiji no što su to druge američke institucije i vrednosti - navodi Frensis Fukujama koji je bio njegov učenik i dodaje da u SAD gotovo da nema konzervativaca evropskog stila, ljudi koji žele da odbrane status quo temeljen na hijerarhiji, tradiciji i pesimističkom gledanju na ljudsku prirodu (Fukujama, 2003). Liberali su predodređeni za optimizam. Zapravo oni koji su u SAD konzervativci u Evropi se nazivaju liberali, jer su za slobodno tržište, individualnu inicijativu i demokratiju zasnivanu na pravima pojedinaca, a ne kolektiviteta. Ako je jedna od definicija konzervativca - čuvar statusa quo - onda se slobodno može kazati da ,,američki konzervativci (poznati i kao klasični liberali) nikad nisu bili od te vrste pa ni politički ciljevi američkih konzervativaca nisu manje revolucionarni“" (Ibid.). Od samog početka, Amerikanci smatraju svoje vrednosti i institucije utelovljenjem univerzalnih težnji koje će jednoga dana imati značaj koji mnogo prevazilazi obale SAD, po tom gledištu, demokratija, ustavna vlast $\mathrm{i}$ individualna prava na kojima one počivaju dobre su 
ne samo za Severnoamerikance zbog njihovih posebnih običaja i tradicija, već za sve ljude sveta - „otud su u svojoj spoljnoj politici Sjedinjene Države sve samo ne sila statusa quo" (Ibid). Opstanak Jugoslavije kao status quo nije bio moguć. Ipak, Amerika će doći u priliku da postane takva sila kada počne da gubi primat moći.

Šta zapravo znači imati konzervativnu spoljnu politiku odgovorio je Frensis Fukujama. Tu se konzervatizam često identifikuje sa onim što stručnjaci za međunarodne odnose označavaju kao realizam, tj. stav da je svetska politika bespoštedna borba nacionalnih država za sticanje i očuvanje moći i samostalnost u pitanjima nacionalne bezbednosti, a njegova suprotnost, liberalni internacionalizam, vidi mogućnost uspostavljanja jednog globalnog poretka zasnovanog na zajedničkim normama i vrednostima koje se provode jednim sve gušćim sistemom međunarodnog prava i međunarodnih organizacija. Fukujama navodi da se „,realisti fokusiraju na ravnotežu snaga i vojnu spremnost; liberalni internacionalisti na institucije, pravila i zakonska ograničenja“" (Ibid).

Realizam kao škola učenja ili teorija, i praksa nije isto, ali je važno napomenuti razvoj tih ideja u prošlosti. Tomas Hobs (Thomas Hobbes) je u jednoj misli iskazanoj u rečenici ,rat svih protiv sviju“ jednostavno uteme-

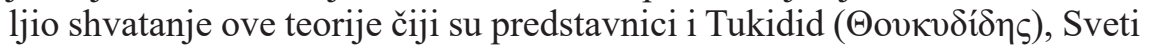
Avgustin (Aurelius Augustinus Hipponensis) i Nikolo Makijaveli (Niccolò di Bernardo dei Machiavelli). Ideja koja je u osnovi realizma je da su se pojedinci organizovali u države i da svaka od njih želi da ostvari svoje nacionalne interese definisane kroz silu. Realistička škola preovlađuje u SAD kao ostatak Hladnog rata i tadašnje ravnoteže snaga. Nakon Hladnog rata došlo je do popuštanja realističkog pristupa i usvajanje elemenata idealističkih pravaca. Vudro Vilson (Thomas Woodrow Wilson) američki predsednik iz perioda Prvog svetskog rata smatra se začetnikom idealističkog usmerenja spoljne politike. Neorealisti su dogradili stavove realizma i današnji svet promišljaju kroz međunarodne strukture koje ograničavaju delovanje država. Intervencionizam se može osloniti i na ovu teoriju, ali po određenim uslovima koji nisu međunarodni nego domaći.

Američka spoljna politika je oduvek išla u dva pravca: prema realističnoj odbrani nacionalne bezbednosti definisane u relativno uskom smislu, i prema ekspanzivnom shvatanju američkih težnji koje se direktno naslanjaju na izuzetnost američkih institucija i mesijansku veru u njihovu univerzalnu primenjivost - bivši državni sekretar Henri Kisindžer (Henry Alfred Kissinger) predstavlja tu realističku struju dok liberalnu internacionalističku tradiciju predstavljaju Vudro Vilson, osnivač Lige naroda ali i republikanske i demokratske administracije, koje su pomogle osnivanju međunarodnih institucija, kao Severnoamerički slobodnotrgovinski sporazum (The North American Free Trade Agreement) i Svetska trgovinska organizacija (The World Trade Organization) (Ibid.). „Američki realisti, počev od Brenta Skaukrofta (Brent Scowcroft), preko Kolina Pauela (Colin Luther Powell), Džejmsa Bejkera (James Addison Baker III), pa do Lorensa Iglbergera (Lawrence Sidney Eagleburger), nisu verovali da Sjedinjene Države treba da preuzmu teret rešavanja balkanske krize, niti bilo koje druge humanitarne krize u svetu“ Robert Kejgan (Robert Kagan) na- 
pominje (Kejgan, 2003: 114).

Šta je dominantna ideologija savremenog Zapada i ko je gospodar u novim uslovima planetarnog rasporeda snaga, kakve su osnovne crte njegovog pogleda na svet, šta on misli o svetu, istoriji, sudbini čovečanstva pitao se Aleksandar Dugin (Александр Гельевич Дугин) i dao odgovor da na Zapadu postoji dominantna ideologija, koja nije manje totalitarna i netrpeljiva od bilo koje druge, samo što ima posebne oblike i principe, drugačije filozofske premise, istorijsku bazu različitu od nama poznatih uobičajenih ideologija - ideologija liberalizma (Дугин, 2000: 689-690). Liberalna ideologija je desničarska u usko ekonomskom smislu i levičarska u smislu humanitarne retorike, pa je na poseban način totalitaran - umesto direktnih fizičkih represalija za one koji drugačije misle, pribegava se taktici blagog gušenja, postepenog istiskivanja na periferiju društva, ekonomskog gušenja disidenata i oponenata (Ibid).

Međunarodni liberalizam jednako je teorija koliko i politička ideologija. Pošto su pobornici ove teorije često i vernici ove ideologije ponekad je teško odvojiti činjenice od uverenja. Kao rezultat liberalna teorija u međunarodnim odnosima obično kombinuje naučne nalaze i fond nadanja, a liberalni teoretičari nalazeći se između objektivnosti i subjektivnosti variraju između objašnjavanja i bodrenja (Puchala, 2003: 189). Kejganovim rečima: „SAD predstavljaju jedno liberalno društvo, i s obzirom na to da veruju u silu, za njih ona mora biti sredstvo unapređenja principa liberalne civilizacije i liberalnog svetskog poretka“" (Kejgan, 2003: 58).

Stiven Larabi (F. Stephen Larrabee) 1994. godine u jednom tekstu navodi da je: ,Jugoslovenski sukob pokrenuo veliku raspravu u SAD o njenim interesima u posthladnoratovskoj eri. Javile su se dve glavne škole mišljenja. Na jednoj strani su neovilsonijanci koji smatraju da bi propust da se izvede jača, iako ograničena, vojna akcija protiv Srba izložio podsmehu pozive SAD za stvaranje novog svetskog poretka i rizikovao da ohrabri buduće agresije. Na drugoj strani su neorealisti koji smatraju da SAD nemaju vitalne interese u Jugoslaviji i da se ne smeju vojno mešati. Debata o Jugoslaviji se, štaviše, ukrstila i dala podsticaj široj debati u američkoj političkoj i vojnoj eliti o upotrebi američke vojne sile u posthladnoratovskoj eri. Dok su delovi Stejt departmenta zagovarali aktivniju politiku SAD u Jugoslaviji, uključujući selektivnu primenu američke vazduhoplovne sile, američka vojska je bila energično protiv upotrebe američkih oružanih snaga u Jugoslaviji, strahujući da bi Jugoslavija mogla biti klizavo tle koje bi uvuklo SAD u dugotrajni, i verovatno unapred izgubljeni, građanski rat" (Simić, 1997: 195).

\section{PRVA KLINTONOVA ADMINISTRACIJA}

U januaru 1993. godine, Vilijem Džeferson Bil Klinton (William Jefferson Bill Clinton) čije je prvobitno prezime bilo Blit (Blythe) je postao četrdeset drugi predsednik SAD, a Al Gor (Albert Arnold Gore Jr.) njegov podpredsednik. Prilikom inauguracije Klinton je izjavio sledeće: „Kada su naši vitalni interesi osporeni, ili se prkosi volji i savesti međunarodne zajednice, mi ćemo delovati mirnom diplomatijom kad god je moguće, 
i uz silu kada je potrebno“ (Clinton, 1993). Da bi Savet bezbednosti UN bio taj koji određuje tu volju još uvek je bilo lako reći, ali je uvedena sintagma savest međunarodne zajednice za koju još nije bilo lako naslutiti pravo određenje. Kasnije se to kristalisalo u vidu saveta, preporuka i medijskog uticaja nove nomenklature motivisanih intelektualaca koji nisu deo zvanične administracije SAD ali imaju uticaj na nju. Tako je došlo do politike uplitanja (engagement).

Klinton je definisan kao liberal unutrašnje politike i realista spoljne politike: „Unutrašnja obnova bila je centralna tema prvog Klintonovog mandata, ali pošto se spoljna politika nije mogla ignorisati, Klintonovo stavljanje težišta na globalizaciju obezbedilo mu je ugodnu formulu da objedini unutrašnju i spoljnu politiku u jedinstvenu, koherentnu temu, što ga je oslobodilo obaveze da definiše i sledi disciplinovanu spoljnopolitičku strategiju“ (Bžežinski 2009, 51). Još pre inauguracije nakon izbora novembra 1992. godine Klinton je razgovarao sa načelnikom generalštaba, koji je odlučio da se posle izbora penzioniše, Kolinom Pauelom koji o tome kaže: „Pitao me je o Bosni - želeo je da zna da li postoji neki način da utičemo na situaciju tamo, recimo kroz vazdušne napade“ (Paueli Persiko, 2001: 611). Još tada je Klinton imao plan korišćenja vazdušnih napada.

Novi predsednik SAD imenovao je Entoni Lejka (William Anthony Kirsopp Lake) za svog savetnika za nacionalnu bezbednost o kome se kaže: „Klinton je bio veoma nestrpljiv kada mu se nameću teme iz spoljne politike koje nemaju očigledno rešenje, kao što je bila Bosna i slično a Lejk ga je obično obaveštavao o ovim stvarima rano ujutru, kada je bio najnervozniji““ (Halberstam, 2003: 372). Lejk, bivši spoljnopolitički službenik, radio je pod Henrijem Kisindžerom koji je predsedniku Niksonu (Richard Milhous Nixon) bio savetnik za nacionalnu bezbednost i kao direktor Odeljenja državne politike za planiranje osoblja za vreme administracije predsednika Kartera (James Earl Carter Jr.). Tokom Karterovih godina, Lejk je bio svedok negativnih efekata birokratskih razmirica između državnog sekretara Sajrusa Vensa (Cyrus Roberts Vance) i savetnika za nacionalnu bezbednost Zbignjeva Bžežinskog (Zbigniew Kazimierz Brzezinski) pa je Lejk bio efikasan u održavanju dobrih odnosa sa državnim sekretarom Vorenom Kristoferom (Warren Minor Christopher) u razvoju atmosfere saradnje. Lejk je u početku održavao nizak javni profil, izbegavajući javne nastupe i televizijske intervjue, kako ne bi potisnuo državnog sekretara kao što je Kisindžer radio Niksonovoj administraciji (History of the National Security Council 1997) Diskretno je pravio pregled osnovnih pitanja aktuelne američke spoljne politike. Izdvajamo tri važna pitanja: Kada su američki interesi najbolje zadovoljeni oslanjanjem na multilateralne mirovne operacije i kada su oni najbolje zadovoljeni akcijama koje su jednostrane ili prethodno nisu odobrene od strane UN-a? Po pitanjima koja se tiču NATO/KEBS-a politika SAD bi trebalo da bude razvijena sa opcijama i predloženim planovima delovanja; Na koji način bi američki obaveštajni sistem mogao obezbediti informacije na redovnoj (a ne ad hoc) osnovi o raznim delovima sistema UN-a i njegovih operacija na terenu (Lake 1993 February).

U septembru 1993. godine kao odgovor na kritike da Klintonova 
administracija nije odgovarajuće objasnila svoju spoljnu politiku, Lejk je počeo da se pojavljuju kao javni govornik. Izdvajamo najznačajnije delove Lejkovog govora održanog u Školi naprednih međunarodnih studija Univerziteta „Džons Hopkins“ (School of Advanced International Studies, Johns Hopkins) pod nazivom „Od zaprečavanja do širenja“ kao svojevrsna strategija kontinuiteta: „...Oni od nas koji veruju u imperativ našeg međunarodnog angažmana ponovo ga moraju podupreti. ...Veliki izazov po našem mišljenju, za našu politiku i međunarodne institucije u ovoj eri je činjenica da se većina sukoba odvijaju u okviru jedne nacije pre nego među nacijama. ...Poslednjih godina, vode se razgovori o tome kada da upotrebimo silu uključujući skup vitalnih pitanja kao što su to da li naše snage dostižu naše ciljeve, da li možemo da se borimo i pobedimo u periodu koji je prihvatljiv, da li imamo razuman izlaz, da delamo ili ne, da li postoji javna podrška Kongresa. Ali smo prevideli strateško pitanje pitanje ,gde“ - koje postavlja kontekst za takve vojne odluke. ... NATO će ostati oslonac evropske i atlantske stabilnosti, kao što i predsednik veruje, a članice moraju da se obavežu na osavremenjavanje uloge NATO-a u ovoj novoj eri. ... Naši napori u Somaliji i Bosni su važan izraz našeg ukupnog angažmana, ali oni po sebi sami ne definišu naše šire strategije u svetu. Sukob u Bosni zaslužuje američki angažman: to je velika humanitarna tragedija, uslovljena etničkim varvarstvima, ona je proistekla iz agresije na nezavisnu državu koja se nalazi u Evropi pored tržišta u nastajanju i novih demokratija koje mogu sve previše lako eksplodirati u širi balkanski sukob. ... vraćamo se na podele i debati o našoj ulozi u svetu koje su stare koliko i naša Republika. S jedne strane je protekcionizam i ograničeno angažovanje u inostranstvu, a na drugoj je aktivno američko angažovanje u ime demokratije i proširenja trgovine“" (Lake 1993 September).

Vidimo iz navedenog teksta da je od bivše Jugoslavije ostala samo Bosna $\mathrm{i}$ to humanitarna tragedija uslovljena etničkim varvarstvima, ona je proistekla iz agresije na nezavisnu državu. Ono što je Bušova administracija propustila da učini, a to je da očuva SFRJ, ubuduće će Klintonova težiti da učini kako za Hrvatsku, tako i za Bosnu i Hercegovinu, ali ne i Srbiju. Naročito će to doći do izražaja od 1995. godine kada je „Bosna postala simbol američke spoljne politike“ (Halberstam, 2003: 408). Srbija, isto tako republika bivše Jugoslavije, nije očuvavana. O doslednosti spoljne politke Vašingtona je teško govoriti. Kako priznaju neke ovdašnje američke diplomate: ,gorka istina je da Amerika nikad nije ni imala doslednu politiku na Balkanu“ (Ignjatijef, 2001: 48). Najvažniji deo Lejkovog izlaganja je zapravo da naslednica doktrine zaprečavanje mora biti strategija proširenja, širenja svetske slobodne zajednice tržišnih ekonomija jer osnovni bezbednosni interesi SAD od toga zavise (Kegley \& Wittkopf, 1996: 72). Izgradnja odgovarajuće prakse bila je problem.

Intelektualac Lejk bio je zagovornik neovilsonizma i video ga kao pragmatski put ka ostvarenju stabilnog sveta koji nije naivno liberalan ni surovo realističan (Friedman, 1993). U vreme predsednika Vilsona cilj i želja da se postigne demokratija američkog tipa na Haitiju 1916. nije ostvarena uplitanjem u revoluciju i posle neuspeha ojačala i prerasla do uverenja kako SAD nemaju drugi izbor nego da nametnu svoja rešenja, čak 
i ako to znači upotrebu sile i vojnu intervenciju (Link, 1960: 549-550). U

pitanju je nametanje demokratije, onako kako je Amerikanci shvataju, bilo kojim načinom, ali je to tada bilo na Karibima gde su SAD hegemon još od Monroove doktrine (James Monroe) 1823. što se na Haitiju i Klintonu 1994. zadesilo. Klintonova doktrina bila bi: „Intervenišemo samo kada ne postoji vitalni interes nacionalne bezbednosti, posebno ako ga podržava domaća interesna grupa, a rizik od žrtava je nizak“ (Clawson, 1997). Žrtve su u smislu državljana SAD.

Mirovne operacije nisu i ne mogu biti centralna tema američke spoljne politike. Međutim, kao što predviđa „Američka politika reforme novih mirovnih operacija“" od 5. maja 1994. godine, pravilno osmišljena i dobro izvršena mirovna operacija može biti koristan element u službi američkih interesa (President Clinton Signs Presidential Decision Directive, 1994). Upravo u ovoj odluci se nalazi izvor američkih interesa na Zapadnom Balkanu koja su delovanjem u kasnijem periodu uokvirena u novu doktrinu.

Predsednička direktiva PDD 25 koju je Klinton potpisao maja 1994. godine je sumirni prikaz stavova administracije o multilateralnim mirovnim operacijama gde se nabrajaju činioci koji se moraju uzeti u obzir pre ulaska u mirovne operacije, a to su: unapređenje američkih interesa, sredstva za obavljanje misije, razmatranje posledica neulaska u akciju, realistički kriterijum za završetak operacije, pristanak sukobljenih strana i prekid oružanog sukoba. Teritorijalni sporovi, oružani etnički sukobi, građanski ratovi, od kojih bi mnogi mogli da se preliju preko međunarodnih granica i kolaps državnih organa u nekim zemljama su među trenutnim pretnjama miru pa iako mnogi od tih sukoba ne mogu direktno da ugroze američke interese, njihov ukupni efekat je značajan (Clinton Administration Policy on Reforming Multilateral Peace Operations, 1996). Propale države i naročito one koje su u procesu raspada su shvaćene kao pretnja.

Dva dana ranije Pola Džons (Paula Jones) podnosi građansku tužbu protiv Klintona pred američkim Okružnim sudom u Litl Roku, Arkanzas, tražeći odštetu od 700.000 dolara za ,svojevoljno, nečuveno i zlonamerno ponašanje' u hotelu Ekcelsior u Litle Roku 8. maja 1991. i optužuje ga da je ,seksualno uznemiravao i napadao“, a zatim i klevetao demantijima (Key events in the Jones v. Clinton lawsuit 1998). Takvog predsednika nije puno ni interesovao sadržaj bilo koje direktive, pa i sasvim nove politike. Bžežinski navodi da je: „Predsednik, osobito u prvom mandatu, bio više učesnik nego dominantni glas, i kada bi se sastanak okončao nije se tačno znalo koja odluka je donesena i da li je uopšte donesena“" (Bžežinski, 2009: 53). Odlučnost će sazreti kasnije.

Neintervencija je konzervativni princip u smislu da poštuje i nastoji da očuva strukturu međunarodnog poretka protiv svih jednostranih promena dok samoopredeljenje, međutim, zahteva od strukture međunarodnog poretka da se promeni da može da podržava intervenciju od strane trećih lica u borbi grupe za nezavisnost od tuđe vlasti (Beitz, 1979: 93). To bi podrazumevalo liberalnu politiku uključenosti Amerike u poslove svih država, ili bar pojedinih na koje se nameri. Milioni Amerikanaca mislili su da je Klintonova administracija ne samo zla već skoro satanska, plašeći se 
njenog internacionalizma kao prikrivenog uvođenja jedne svetske vlade, „,novog svetskog poretka“ (Dženkins, 2002: 240).

Sklapanje Dejtonsko-Pariskog mirovnog sporazuma za Bosnu i Hercegovinu je dalo Klintonu novu snagu na temelju uspeha spoljne politike (Мирков, 2016: 345-361). Mediji, javnost i glasači u SAD su dobro nagradili njegovu administraciju. Klinton je ubedljivije nego prvi put, ali opet sa manje od polovine glasova pobedio republikanskog kandidata, ovog puta Boba Dola (Robert Joseph Dole) i još jednom ostavio na trećem mestu nezavisnog Ros Peroa (Henry Ross Perot).

\section{DRUGA KLINTONOVA ADMINISTRACIJA}

Sendi Berger (Samuel Richard Berger) kao novi savetnik za nacionalnu bezbednost je inicirao reviziju principa spoljne politike drugog Klintonovog mandata (1997-2001). Berger koji je bio Lejkov zamenik od 1993. godine i dugogodišnji Klintonov savetnik za spoljnu politiku, postao je savetnik za nacionalnu bezbednost marta 1997. godine, nakon što je Klinton nominovao Lejka za direktora CIA koji se kasnije povukao iz nominacije. Promena u spoljnoj politici uključivala je integraciju Istočne i Zapadne Evrope, bez izazivanja tenzija sa Rusijom, promovisanje otvorene trgovine, poboljšanja odbrane od transnacionalnih pretnji kao terorizam i droge, pa se u proleće i leto 1997. godine, Savet za nacionalnu bezbednost bavio pitanjima kao što je proširenje NATO-a (History of the National Security Council, 1997). Osim članstva, trebalo je i geografski povećati oblast delovanja.

$\mathrm{Na}$ mestu državnog sekretara umesto Vorena Kristofera, koji pored mlađeg predsednika Klintona nije bio primetan u svojoj ulozi i skoro neprimetno nestao sa scene, našla se Medlin Olbrajt (Madeleine Albright, ranije Jana Korbel) koja je do tada bila ambasador SAD pri UN. „Ubrzo pošto je postala prva žena na položaju državnog sekretara, obratila se za savet diplomatama i spoljnopolitičkim stručnjacima koji su zagovarali doktrinu ,humanitarnog intervencionizma‘: Zbignjevu Bžežinskom, Mortonu Abramovicu (Morton Isaac Abramowitz), Džordžu Sorošu (George Soros, ranije György Schwartz) i Lesli Gelbu (Leslie Howard Gelb) predsedniku Saveta za spoljne odnose (The Council on Foreign Relations). Očigledno je želela da novu doktrinu što pre proveri u praksi čak i po cenu da jedan komplikovan i star etnički spor, kao što je kosovska kriza, stavi u problematične okvire, humanitarnog intervencionizma' u čemu je krupnu ulogu odigrao upravo Morton Abramovic koji je već od Dejtonskog sporazuma aktivno podržavao separatistički pokret na Kosovu da bi se na konferenciji u Rambujeu pojavio u ulozi glavnog političkog savetnika albanske delegacije, a to je išlo na ruku tzv. „Oslobodilačkoj vojsci Kosova“ (OVK, Ushtria Çlirimtare e Kosovës - UÇK) koja je podsticala oružani sukob i humanitarnu krizu upravo da bi obezbedila podršku najmoćnijeg vojnog saveza u savremenom svetu za svoje ciljeve“" (Симић, 2000). Morton Abramovic se može smatrati jednim od vodećih autora doktrine humanitarnog intervencionizma, a geopolitičku dimenziju novog strateškog koncepta NATO-a razradio je Zbignjev Bžežinski u nizu govora, članaka i 
u knjizi Velika šahovska tabla: američki primat i njegovi geopolitički ciljevi (Ibid., Zbignjev Bžežinski 1999). Pretvaranje jedne zemlje srednje veličine poznate po otporu imperijama kao što je Jugoslavija, u niz nacionalnih državica u kojima se jeftino eksploatišu prirodna bogatstva i obrazovana radna snaga i gde se mogu praviti vojne baze SAD kao odskočna daska prema Kaspijskom basenu bogatom naftom je prepoznatljivo u ovom delu Bžežinskog. Trebalo je naći način kako.

Henri Kisindžer kaže da: „Nova doktrina humanitarne intervencije polazi od pretpostavke da su humanistička uverenja toliko duboko ukorenjena u američku tradiciju da se u njihovu odbranu, bilo gde u svetu, mora rizikovati imovina, i u izuzetnim slučajevima, ljudski životi“" (Kisindžer, 2003: 284). Naravno, ako može bez gubitaka američkih života. „Humanitarna intervencija pripada idealističkom pristupu, koji naglašava promociju vrednosti pri vođenju spoljne politike i priklanja se uverenju da spoljne politike posebnih zemalja mogu, a ponekad to i čine, menjati svet na bolje“" (Mandelbaum, 2006: 70-71). Stabilan i siguran međunarodni poredak koji olakšava trgovinu je svakako globalni cilj. Posebna ili izuzetna zemlja u ovom slučaju je Amerika kao jedina kojoj pripada to pravo da menja stvari na bolje za sebe i svoje saveznike.

Kisindžer navodi da: „Zemlje u razvoju uglavnom interpretiraju doktrinu humanitarne intervencije kao mehanizam pomoću koga industrijske demokratije potvrđuju neokolonijalnu hegemoniju“ (Kisindžer, 2003: 295). Na to dodaje: „Vilsonovski principi su bili dominantna motorna snaga zapadne spoljne politike na Balkanu - u Bosni da okonča surovi građanski rat i na Kosovu, u suštini, da prenese vlast sa Srbije na većinu stanovništva, koje je etnički albansko“ (Ibid: 285, 286). Kisindžer još piše: „U Bosni je bila reč o građanskom ratu u zemlji koja je formalno priznata od UN nakon raspada Jugoslavije“ (Ibid: 292). Kisindžer dalje određuje izopačenost izmenjenih principa koji više nisu univerzalni: „Kad se bliže pogleda, postaje očigledno da osnovni princip nove etičke spoljne politike nije primenjivan na velike zemlje, niti na njihove saveznike, kao ni na zemlje koje imaju značajnu domaću konstituantu u većim demokratskim društvima“ (Ibid: 289). Pravila ne važe za SAD i koaliciju koju oni predvode i jake zemlje koje mogu da se odupru ili utiču na drugi način, savez.

Za vreme drugog Klintonovog mandata, njegov specijalni izaslanik za Balkan Ričard Holbruk (Richard Charles Albert Holbrooke) kao i u prvom, je govorio da ,američku politiku na Balkanu stvara neformalna ,ekipa“ koju zove po imenima: Sendi (Berger), savetnik za nacionalnu bezbednost, Stroub (Talbot), zamenik državnog sekretara i Medlin (Olbrajt)“" (Ignjatijef, 2001: 16).

Koliko je Medlin Olbrajt stala u odbranu nove američke uloge u svetu vidi se i po njenoj izjavi datoj 1996. godine u emisiji 60 minuta (60 minutes, CBS News, TV airdate 12 May 1996) novinarki Lesli Stal (Lesley Rene Stahl) na čije je pitanje o dugogodišnjim ekonomskim sankcijama Iraku i informaciji UN-a da je zbog toga umrlo pola miliona dece, mnogo više nego u Hirošimi, odgovorila: „Mislim da je to težak izbor, ali ova cena, mi mislimo - da je ta cena vredna toga" (FAIR 2011). Nije odredila u odgovoru čega je to vredna cena, ali nije ni novinarka prećutavši hege- 
moniju njihove države na celoj planeti. Iako se Medlin Olbrajt ogradila i rekla u množini „mi mislimo“ da je vredno naškoditi životima nevinih koji nemaju uticaja na odluke diktatora i prouzrokovati njihovu smrt, ova izjava nije doprinela dobrim odnosima SAD i muslimansko-arapskog sveta. Zapravo sama činjenica da je takva spoljna politika vođena prema narodu jedne zemlje drugog civilizacijskog kruga neumitno je vodila do događaja od 11. septembra 2001. godine. Bespomoćnost dece, i odraslih stvorila je želju za odmazdom baš tog datuma na jedanaestogodišnjicu uvođenja Novog svetskog poretka od strane oca istoimenog tadašnjeg američkog predsednika Džordža Buša..

Medlin Olbrajt je poznata po još jednoj izjavi snimljenoj za televizijsku publiku 1999. godine pre bombardovanja SRJ, na srpskom jeziku, a ona počinje sa: „Amerikanci ne mrze Srbe“ (Albright, 1999). Nije jasno da li je i ta rečenica bila samoubeđivanje, opravdanje svetskoj javnosti ili samo interes uticaja na javnost bez pravog upliva emocija. Jasno je da obični građani SAD ne mrze Srbe i da obe nacije pripadaju hrišćanstvu i istom filozofskom krugu. Zato i nije bilo uzvratnih napada na Ameriku i njene građane od strane Srba, ali to nije sprečilo mnoge scenariste u SAD da osmisle filmove u kojima su Srbi teroristi, kao što su prikazivani i Arapi. Primer je film Mirotvorac scenariste Majkla Šifera (Michael Schiffer), u režiji Mimi Lejder (Mimi Leder), producenta Branka Lustiga u kome diplomata Republike Srpske pribavlja male nuklearne bombe ukradene u Rusiji i nosi jednu u Njujork da je aktivira u zgradi UN kako bi osvetio svoju porodicu pobijenu u ratu. Devet marinaca SAD ginu nakon što su helikopterom ušli na teritoriju Rusije sprečavajući širenje oružja za masovno uništenje, dok IFOR u Bosni upada u kuću diplomate, a na Menhetnu Srbi ubijaju dva policajca da bi na kraju u crkvi pre deaktiviranja pukovnik SAD rekao: „To nije naš rat”, a Srbin pre pogibije odgovorio: „Sada jeste” (The Peacemaker, 1997).

Zabava koja se postiže filmom kao fikcijom ipak ostavlja utisak na građane SAD koji se retko pitaju o spoljnoj politici, ali čine osnov političkog života svojim glasanjem i uticanjem na druge načine. Posle takvog filma ko ne bi osećao barem određeni strah ili bar sumnju u dobre namere Srba prema SAD, ako ne i mržnju za koju je u trenutku dok ih bombarduje, američki državni sekretar izjavila da je nema. U svakom slučaju izjava nije pomogla narodu i zemlji u kojoj je Medlin Olbrajt našla utočište sa roditeljima kao dete dok je bila izbeglica iz Čehoslovačke, odakle je poreklom. Posle bombardovanja insistira se na odvajanju Kosova i Metohije uprkos Vojno-tehničkom sporazumu u Kumanovu sa NATO snagama i Rezoluciji 1244 Saveta bezbednosti UN.

Kao pojačani nastavak politike koju su uobličavali Medlin Olbrajt i njeni saradnici i savetodavci, brojni bivši zvaničnici administracije bivšeg predsednika Buša, koji se od 1997. predstavljaju pod imenom „Projekat za novi američki vek" (The Project for a New American Century), podneli su 2000. godine manifest za dolazećeg predsednika: „Obnova američke odbrane - Strategija, snage i resursi za novi američki vek“ koji je produžetak Dokumenta o smernicama odbrane iz 1992. godine napisan od strane Pola Volfovica, a potpisan od mnogo ljudi koji su ubrzo i vodili američ- 
ku spoljnu politiku (Donnelly, Kagan \& Schmitt, 2000). Sveobuhvatnom promenom taktike koja se sprovodila pola veka, dokument je potpuno odbacio multilateralizam. „Projekat za novi američki vek“ je likovanje nad tim da se sa kolapsom komunizma pojavila nova perspektiva i poziva na jednostranu globalnu hegemoniju jedine supersile na svetu navodeći da se „U ovom trenutku Sjedinjene Države ne suočavaju sa globalnim rivalom. Američka Velika strategija treba da ima za cilj očuvanje i proširenje ovog povoljnog položaja što je dalje moguće u budućnost" (Atwood, 2010: 223). U sličnom tonu bila je i spomenuta knjiga Zbignjeva Bžežinskog o američkom primatu, Velika šahovska tabla. Kina, pa i Rusija jesu rivali na koje se računalo, ali mnogo kasnije u ovom veku.

\section{ZAKLJUČNA RAZMATRANJA}

Činjenica je da je ishod raspada Jugoslavije mogao biti gori da se ova zemlja nalazila van Evrope ili da je na njenom tlu nađeno više nafte i gasa. Tada bi posledice po građane bile kao u Iraku ili Libiji. SAD snose krivicu za mešanje u sukob na jednoj strani radi pojednostavljivanja etničkog stanja na terenu proterivanjem jednog etniciteta (primer Krajina) ili suzdržavanje od pružanja dobrih usluga na početku krize navodeći na odustajanje od postignutog dogovora za Bosnu i Hercegovinu pre rata (Kutiljerov plan za Bosnu i Hercegovinu) ili namećući jednostrano odvajanje Kosova i Metohije diktatom Srbiji posle rata kako bi se steklo naknadno moralno opravdanje za bombardovanje (uvođenjem UN u proces). Na Kosovu imperativ promocije demokratije bledi. SAD su prostor Balkana koji je bio u težištu sukobljenosti interesa u Hladnom ratu sada htele potpuno da zauzmu (Мирков, 2020: 276).

Narušavanjem svih principa, od autoriteta Saveta bezbednosti UN do drugačijih standarda, nametanja statusa pre demokratizacije i ekonomske stabilizacije, Vašington ima nameru da stvori uslove prisilne poslušnosti za jedne i dužne odanosti za druge u regionu po manihejskoj podeli na prijatelje i neprijatelje. Interesi su Americi zapravo ono što čini osnov podele, ali, gledano mehanički, bez udubljivanja u temu i sadržaj odnosa, to kvari odnose u budućnosti i generator je nestabilnosti regiona. Kada se Amerika umeša u neki spor podržavajući jednu stranu, tada je ta strana manje sklona kompromisu, što se pokazalo i u bivšoj Jugoslaviji - i to na štetu srpske strane u svakom od slučajeva na Balkanu. Pojednostavljeni prikaz sukoba je odredio ko je dobar, a ko loš u regionu i naveo na trajan odnos prema jednom etnicitetu na Balkanu kao dežurnom krivcu kom uvek sleduje trpno stanje u svakom pogledu.

Srbija i Srbi kao etnicitet pripadaju istom filozofskom krugu kom su nekada pripadale i SAD i Zapad uopšte, dok religijski pripadaju hrišćanstvu, a hantingtonovski gledano pravoslavnoj civilizaciji i svakako su u Evropi. Tektonske promene $\mathrm{u}$ američkom prilazu rešavanju međunarodnih problema dovele su do promene statusa prava i tumačenja ugovornih obaveza međunarodnog karaktera, naročito prema Ujedinjenim nacijama. Ravnoteže u globalnim odnosima nije bilo 1990-ih godina, ali se stvorila nada da će u novom veku (američkom, kako su ga nazvali konzervativci u 
SAD) biti više poštovani i interesi drugih jer se multipolarnost već nazire. ЛИТЕРАТУРА

Atwood, Paul L. War and Empire: The American Way of Life. New York: Pluto Press, 2010

Albright, Madeleine K. „Remarks to the Serbian People“. Washington, D.C.: Secretary of State, March 26, 1999, Internet https://1997-2001.state.gov/ statements/1999/990326c.html 09/02/2021

Beitz, Charles R. Political theory and international relations. New York: Princeton University Press, 1979

Bergner, Džefri T. Novi svetski poredak: Nove super sile Nemačka, Japan, SAD. Beograd: Beletra, 1994.

Bush, George H. W. „Address Before a Joint Session of the Congress on the Persian Gulf Crisis and the Federal Budget Deficit" 1990-09-11, The George Bush Presidential Library and Museum, Public Papers, Internet https://bush41library.tamu.edu/archives/public-papers/2217 05/02/2021

Bžežinski, Zbignjev. Velika šahovska tabla: američki primat $i$ njegovi geopolitički ciljevi. Podgorica: CID, 1999.

Bžežinski, Zbignjev. Druga šansa Amerike: Tri predsednika i kriza američke supersile. Beograd: Službeni glasnik, 2009.

Clawson, Patrick. „The Clinton Doctrine“. The Washington Institute for Near East Policy, Dec 28, 1997, Internet https://www.washingtoninstitute. org/policy-analysis/clinton-doctrine 29/01/2021

Clinton, William J. „Inaugural Address“. Washington D.C. January 20, 1993, Internet, https://www.presidency.ucsb.edu/documents/inauguraladdress-51 16/01/2021

Clinton Administration Policy on Reforming Multilateral Peace Operations (PDD 25), Bureau of International Organization Affairs, U.S. Department of State, Publication Num. 10161, Washington, February 22, 1996, Internet, http://www.fas.org/irp/offdocs/pdd25.htm 11/01/2021

Donnelly, Thomas, Donald Kagan \& Gary Schmitt. Rebuilding America's Defenses: Strategy, Forces and Resources for a New American Century. Washington D.C.: The Project for a New American Century, 2000. Internet, https://wikispooks.com/w/images/3/37/RebuildingAmericasDefenses.pdf $18 / 01 / 2021$

Дугин, Александр. Основы геополитики: Геополитическое будущее России. Мыслить пространством. Москва: АРКТОГЕЯ-центр, 2000.

Dženkins, Filip. Istorija Sjedinjenih Država. Beograd: Filip Višnjić, 2002.

FAIR. „Mistakes, Madeleine Albright and Dead Iraqi Children“, Fairness \& Accuracy In Reporting, Inc. July 2011, Internet, https://fair.org/ uncategorized/mistakes-madeleine-albright-and-dead-iraqi-children $02 / 02 / 2021$

Friedman, Thomas L. „Clinton's Foreign Policy: Top Adviser Speaks Up“. The New York Times, New York, Oct. 31, 1993, Internet https://www. nytimes.com/1993/10/31/world/clinton-s-foreign-policy-top-adviser- 
speaks-up.html 19/01/2021

Fukuyama, Francis. „The End of History?“. The National Interest, Washington, DC: The Center for the National Interest, No 14, Summer 1989, pp. 3-18

Fukujama, Frensis. „Američki konzervativizam“. Odjek, Proljeće 2003.

Gellman, Barton. „Keeping the U.S. First; Pentagon Would Preclude a Rival Superpower". The Washington Post, Washington, D.C. Mar 11, 1992 A.01, Internet, http:/goodtimesweb.org/overseas-war/2014/wp-pentagon-usrival-superpower-mar-11-1992.html 29/01/2021

Halberstam, Dejvid. Rat u vreme mira: Buš, Klinton i generali. Beograd: BMG, 2003.

History of the National Security Council 1947-1997, Office of the Historian, Bureau of Public Affairs, United States Department of State, Washington, August 1997, Internet, http://www.fas.org/irp/offdocs/NSChistory.htm $10 / 01 / 2021$

Huntington, Samuel P. „The Clash of civilizations“. Foreign Affairs Vol. 72, No3, Summer 1993, pp. 22-49

Ignjatijef, Majkl. Virtuelni rat. Beograd: Biblioteka Samizdat Free, B92, 2001.

Kegley, Charles W. \& Eugene R. Wittkopf. American Foreign Policy: Pattern \& Process, Fifth edition. New York NY: St. Martins Press 1996.

Kejgan, Robert. O raju i moći: Amerika i Evropa u novom svetskom poretku. Beograd: Čarobna knjiga, 2003.

Key events in the Jones v. Clinton lawsuit, The Washington Post, Washington 1998 Internet, https://www.washingtonpost.com/wp-srv/politics/special/ pjones/timeline.htm 20/01/2021

Kisindžer, Henri. Da li je Americi potrebna spoljna politika: U susret diplomatiji XXI veka. Beograd: BMG, 2003.

Krauthammer, Charles. „The Unipolar Moment“. Foreign Affairs, Vol. 70, No 1, Winter 1991, pp. 23-33

Lake, Anthony. Multilateral Peacekeeping Presidential Review Directivel NSC-13, Washington D.C. The White House, February 15, 1993, Internet, http://www.fas.org/irp/offdocs/prd/prd-13.pdf 27/01/2021

Lake, Anthony. From Containment to Enlargement, Remarks of Assistant to the President for National Security Affairs, Washington, D.C. Johns Hopkins University School of Advanced International Studies, September 21, 1993, Internet, http://www.mtholyoke.edu/acad/intrel/lakedoc.html $28 / 01 / 2021$

Link, Arthur S. Wilson, Volume III: The Struggle for Neutrality, 1914-1915. Princeton, New Jersey: Princeton University Press, 1960.

Mandelbaum, Majkl. Treba li svetu golijat? Beograd: Filip Višnjić, 2006.

Мирков, Жељко. „Делатност Ричарда Холбрука у својству специјалног изасланика председника Америке 1995. године“. Српска политичка мисао 51, 1 (2016): 345-361. doi.org/10.22182/spm.5112016.17 
Мирков, Жељко. „Депеше америчких дипломата као извор за проучавање стварања Балканског пакта 1953-1954. године“. Архив XXI, 1-2 (2020): 260-277.

Pauel, Kolin i Džozef Perisko. Jedna američka priča. Beograd: BMG, 2002.

Puchala, James Donald. Theory and history in international relations. London: Routledge, 2003.

President Clinton Signs Presidential Decision Directive Establishing „U.S.Policy on Reforming Multilateral Peace Operations." Washington D.C. The White House, May 5, 1994, Internet, http://www.fas.org/irp/ offdocs/pdd25.htm 18/01/2021

Simić, Predrag. „SAD, NATO i Jugoslovenska kriza”. U Savremeni procesi $i$ odnosi na Balkanu, priredili Stojković Momir i Damian Ana, 193-204. Beograd: Institut za međunarodnu politiku i privredu, Centar za međunarodne studije Fakulteta političkih nauka, 1997.

Simić, Predrag. Put u Rambuje: Kosovska kriza 1995-2000. Beograd: Nea, 2000.

The Peacemaker (1997), DreamWorks, Spielberg-Katzenberg-Geffen, Internet Movie Database, Internet, https://www.imdb.com/title/tt0119874/ videogallery/?ref_=tt_pv_vi_sm 12/01/2021

\title{
THEORETICAL AND DOCTRINAL FRAMEWORKS OF IMPOSING AMERICAN INFLUENCE IN THE BALKANS DURING 1990'S
}

\begin{abstract}
Summary
American foreign policy in the post-bipolar era was based on Western unilateralism theoretically and institutionally, finding support in liberalism and realism because both utilitarian worldviews were inspired by benefit led by Washington's interest. In the 1990s, a number of theorists and officials from both Clinton's administrations influenced the world with neowilsonian enlargement and engagement, irreversibly diminishing the consensus at the United Nations. America keept for itself important decisions introducing political precedents wanting to justify them by international law, explaining it as necessary. Subsequently seeking legitimacy from the UN Security Council for humanitarian intervention gave basis for the survival of the UN, but achieved permanent distrust of small nations, especially Serbs who felt the shortcomings of the unprincipled Washington's foreign policy.
\end{abstract} kan.

Key words: America, theory, institutions, liberalism, realism, Bal- 